\title{
Tennessee
}

\section{Studies in the Great Smoky Mountains National Park}

The Great Smoky Mountains National Park encompasses the last remaining large mountain wilderness in the Eastern United States and provides an unparalleled diversity of habitats ranging from the spruce-fir forests of mountain peaks to limestone caves in historic Cades Cove. To assist management of this biological treasure, the U.S. Geological Survey (USGS), in cooperation with the National Park Service (NPS), is conducting several projects and studies within the park.

One of these studies will provide a new, detailed geologic data base. Specific issues addressed by this study include the identification of hazardous debris flows and areas susceptible to landslides, the distribution of iron- and sulfide-rich slates that can acidify streams and kill fish, the geologic setting of abandoned copper mines which may produce acid-mine drainage, and the location and characterization of boulder deposits that provide habitat for rare and endangered species. Geologic information developed by the project may be used by the U.S. Department of Agriculture to produce new, more detailed soils maps of the park and by the NPS to provide an integrated set of outreach products for park visitors, including publications, exhibits, and museum specimens.

The USGS and NPS are assessing water-quality conditions and ecosystem functions in the park. Many of the older, high-elevation forest ecosystems in the park are experienc- ing nitrogen saturation, which occurs when the amount of nitrogen entering the ecosystem exceeds the amount taken up by the vegetation and soil microbes. The excess nitrogen can lead to soil acidification and increased nitrate concentrations and loads in the surrounding streams. Noland Creek, which drains one of the higher-elevation watersheds of the park where relatively high nitrate concentrations have been detected, has been selected for a long-term study of the effects of atmospheric deposition on streamwater chemistry. Weekly water-quality sampling and monthly aquatic insect monitoring are being conducted at the park by the NPS. The USGS is assisting with stormwater monitoring to assess water-quality conditions during storms and to quantify the effects associated with storms on the aquatic chemistry and biota of Noland Creek.

In addition to the acidification associated with atmospherically derived nitrates, some of the park's streams are affected by acidic minerals, such as pyrite (fool's gold) and pyrrhotite, which occur naturally in some bedrock formations. Disturbance of these formations by landslides and road construction increases the acid-producing capabilities of these rocks and can lead to increased stream acidification and damage to native trout populations. USGS studies of the geology of landslide debris flows and the geochemistry of the resulting drainage provide information on the chemical composition of the drainage and information on the effects on aquatic ecosystems. These data are being used to develop models to describe the changes in water chemistry resulting from landslides, particularly as related to possible water-quality effects on native brook trout.

The park is home to 41 species of amphibians, including the most diverse variety of salamander species in the United States. To help the NPS keep track of amphibian species, the USGS has set up a prototype monitoring and inventory project in the park. The methods developed during the 3year study will provide scientificallybased guidelines for documenting amphibian population trends, which are declining in many areas throughout the world, including national parks.

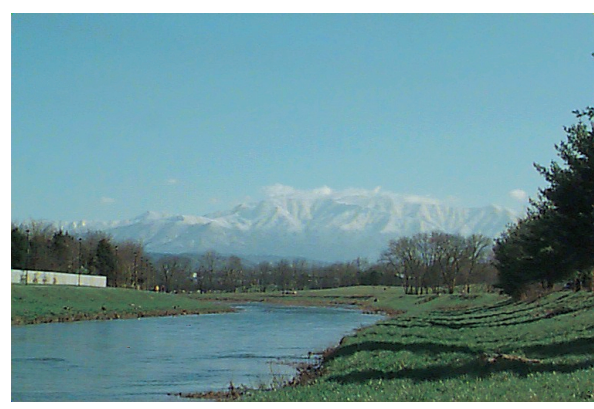

Figure 1. The Great Smoky Mountains National Park.

\section{Mussel Habitat Studies in East Tennessee}

Of the approximately 500 species that compose the entire freshwater mussel fauna of the world, 130 species have been found in Tennessee. Of the species that are native to Tennessee, 11 are presumed extinct, and 38 others are listed as endangered by the U.S. Fish and Wildlife Service. Moreover, populations of many of the 
remaining species are declining, and, if present trends continue, they could also become candidates for listing as endangered or threatened.

Much of the formerly prime mussel habitat, especially in the Tennessee and Cumberland River basins, was destroyed by the construction and operation of dams. For example, reservoir releases from Douglas Dam on the French Broad River in East Tennessee resulted in severe oxygen depletion downstream and are largely responsible for the almost total destruction of mussels and many fish species. Recently, the Tennessee Valley Authority (TVA) began a major program to improve the water quality of reservoir releases, which has resulted in great improvements in habitat below Douglas Dam. Fish populations have significantly increased, and the quality of water in this area again appears to be suitable for sustaining mussel populations, including endangered species.

The USGS, in cooperation with the TVA, the U.S. Fish and Wildlife Service, and the Tennessee Wildlife Resources Agency, has begun an ambitious program to reestablish mussels in the French Broad River. During fiscal year 1998, more than 7,000 adult mussels were relocated to the river and, although this is an ongoing multi-year study, survival of relocated mussels has been excellent. These results indicate that the decline

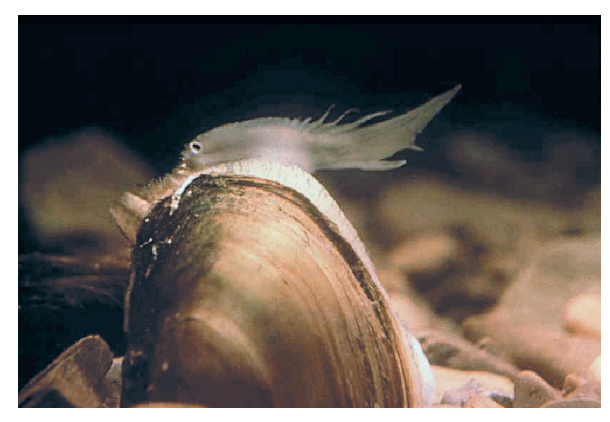

Figure 2. A pocketbook mussel (Lampsilis ovata) in the upper Tennessee River Basin. of Tennessee's mussel fauna might be reversed, reducing the likelihood of additional species being listed as endangered.

\section{Dynamics of a Fish Community in a Tennessee Reservoir}

Beginning in 1991, USGS researchers from the Tennessee Cooperative Fishery Research Unit at Tennessee Technological University studied fish community response to water-level changes and habitat enhancements in TVA's Normandy Reservoir. Manipulation of habitat and water levels are believed by scientists to be the two most important tools available to biologists for the conservation of freshwater fish populations, particularly in reservoirs of the southeastern United States. The results of this research clearly demonstrated that maintaining high water levels during spring spawning seasons is beneficial for forage and sport fish communities. Habitat enhancement, however, was of little benefit in increasing reproduction and survival rates of economically important species.

\section{Earthquake-Hazard Maps for the Memphis Urban Area}

The Memphis metropolitan area is one of three sites in the Nation chosen by the USGS for urban earthquake-hazards mapping. Products of the study will include surface geology maps, a data base of subsurface geology, ground-failure susceptibility maps, and ground-motion maps. Although the USGS has produced a national-scale earthquakehazards map, it is of limited use on a local scale and does not consider local geologic and soil conditions. The more detailed maps resulting from this study, developed from seismic interpretations and geophysical and lithological logs of wells, will be more useful to emergency response planners, the insurance industry, and urban planners and engineers. Organizations cooperating with the USGS in this effort include the Mid-America Earthquake Center (a National Science Foundationfunded consortium of universities including the University of Memphis, the University of Illinois, Saint Louis University, Georgia Institute of Technology, and the Massachusetts Institute of Technology), the University of Kentucky, and the Ground Water Institute at the University of Memphis.

\section{Appalachian Region Coal Assessment}

About 60 percent of the Nation's electricity is generated from coal, and the Appalachian Basin is the largest producer of coal in the United States. Although Tennessee's coal production has declined over the last several decades, about 3,700,000 tons of coal continue to be produced annually. The USGS, in cooperation with the Tennessee Division of Geology (TDG), has been revising coalresource maps and resource estimates for selected areas in the Tennessee coal field. As stratigraphic and coalquality data are verified, they are entered into the USGS National Coal Resources Data System for further interpretation. The ultimate goal is to publish timely coal-resource estimates that can be updated regularly as needed for Tennessee's 20 coalbearing counties.

In 1992, the TDG, under the auspices of the USGS Coal Availability/ Recoverability Studies project, initiated a study to collect, analyze, and depict data defining the relation between mining restrictions and development potential for coal resource areas. The ultimate goal of that study is to determine the eco- 
nomic potential for coal recovery in the study area. The recoverable amounts are expected to be less than 10 percent of the original resource, based on similar studies in Kentucky.

The USGS, in cooperation with the TDG, the University of Tennessee, and the Oak Ridge National Laboratory, is engaged also in a study of deep hydrocarbon resources of the region. The study is designed to define lower Paleozoic petroleum systems in the central Appalachian Basin in eastern Tennessee and adjacent States, in support of exploration and to improve capabilities for the assessment of the Nation's undiscovered oil and gas resources.

\section{Collection of Hydrologic Data}

The USGS, in cooperation with numerous Federal, State, and local agencies, collects hydrologic data to meet the needs of many users. These data document current conditions and provide a basis for understanding hydrologic systems and solving hydrologic problems. In Tennessee, the USGS records streamflow continuously at 61 gaging stations equipped with recorders and makes instantaneous measurements of streamflow at many other stations. Ground-water levels are monitored statewide, and the physical, chemical, and biological characteristics of surface and ground waters are analyzed. USGS activities also include the annual compilation of water-use records and collection of data for national baseline and water-quality networks, and the national atmospheric-deposition program.

USGS data are applied by Federal, State, and local government agencies and water managers to manage the State's water resources. For example, satellite-transmitted data describing current river conditions are used by the Corps of Engineers and the TVA to control the reservoir systems on the Tennessee and the Cumberland Rivers in response to floods and droughts and to determine the appropriate times for waste disposal by cities and towns along the State's rivers. Long-term data— going back in time for more than 100 years - are used routinely to manage river flood-

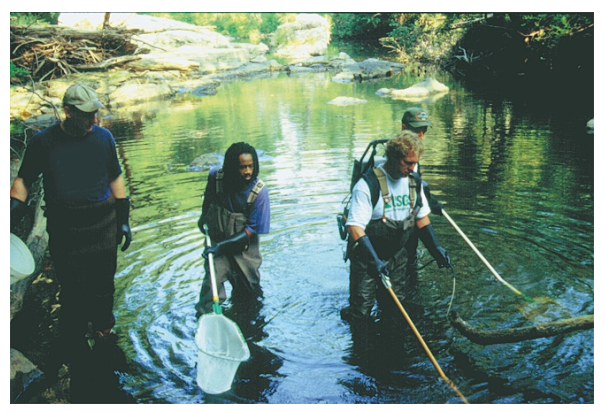

Figure 3. Data collection in the lower Tennessee River Basin.

plain development, to determine flood-insurance rates and trends in water availability and quality, to project and plan for future water demand, and to conduct interpretive studies of water-related problems that may affect many thousands of people.

\section{Statewide Water-Use Information Program}

The USGS Tennessee Water-Use Information Program is conducted in cooperation with the Tennessee Department of Environment and Conservation, Division of Water Supply. The need for detailed wateruse information for Tennessee has become increasingly important as competing demands on local surfaceand ground-water resources continue to increase. Detailed accounting of the rate at which water resources are being used and the location where the demands are greatest is needed to develop management strategies to ensure both sufficient water supply and adequate water quality. A state- wide survey of water use for 1995 was conducted during 1996 as part of a long-term program in which a survey is completed every 5 years to estimate water use in the United States. Ground- and surface-water withdrawals and ancillary data were collected for the major water-use categories of thermoelectric power, agriculture (including irrigation), domestic and commercial purposes, industry and mining, and public use and conveyance losses. Data were compiled at the county, watershed, and aquifer level.

\section{Chlorinated Solvents in Karst Regions}

The USGS, in cooperation with the Tennessee Division of Superfund, is investigating the occurrence, transport, and fate of chlorinated solvents in the karst areas of Tennessee. Chlorinated solvents have been used in many industrial operations and have proved to be persistent, mobile contaminants that can be difficult to remove from ground-water systems. Throughout Middle and East Tennessee, karst aquifers serve as significant sources of water for domestic and public supplies. Chlorinated solvents in karst aquifers can migrate to considerable depth as dense nonaqueous-phase liquids (DNAPL's), which can accumulate and act as a source of dissolved-phase contaminants in ground water. Because of these properties, relatively small amounts of chlorinated DNAPL have the potential to contaminate ground water over a large area for decades or longer. This joint investigation has developed conceptual models to describe contaminant movement and accumulation in karst aquifers to assist in site characterization and the evaluation of clean-up alternatives. Scientists are evaluating natural and enhanced bioremediation of chlorinated solvents at selected karst sites 
in Tennessee and assessing various soil-gas and surface geophysical methods to characterize distributions of volatile organics at contaminant sites in karst aquifers.

\section{The Multi-Resolution Land Characterization Program}

The Multi-Resolution Land Characterization (MRLC) is a national USGS program that collects baseline land characterization data at various scales. MRLC land classifications are derived by applying a generalized Anderson system to mosaics of Landsat thematic mapper images collected every 5 years. The USGS has used the Anderson classification system to classify land use and land cover for the past 25 years. The resulting data and images, which are available to the public, are used primarily by the U.S. Environmental Protection Agency to monitor change in land cover and inferred land use. Preliminary coverage of the State of Tennessee was completed by the USGS under this program in 1998.

\section{Aerial Photography Flown, Digital Orthophoto Quadrangles in Production}

During the spring 1998 leaf-off season, the National Aerial Photography Program acquired black-andwhite aerial photographs of Tennessee. The entire State now has Digital Orthophoto Quad (DOQ) coverage, or is planned for DOQ coverage.

The USGS, in cooperation with the Farm Services Agency of the Natural Resources Conservation Service, is producing DOQ's for selected coverages. A delivery schedule for the DOQ's to be publicly available has been established. Status information concerning availability of the DOQ's can be found on the USGS World Wide Web site: http:// mapping.usgs.gov/www/products/ status.html

\section{National Water-Quality Assessment Program}

The National Water-Quality Assessment Program was established to describe the status of and trends in the quality of a large, representative part of the Nation's surface and ground waters and to identify the natural and human factors that affect the quality of these resources. Information produced is used by policymakers and managers at local, State, and national levels for making decisions and managing the quality of much of the water resources of this country.

The national assessment consists of 59 study units that encompass parts of

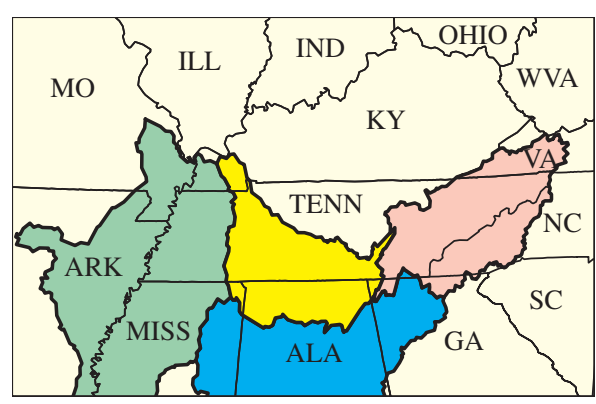

EXPLANATION

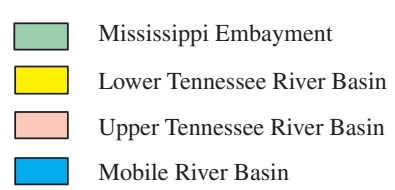

Figure 4. National Water-Quality Assessment Program study units that include Tennessee.

most major river basins and aquifer systems in the Nation. Four of the study units include regions in Tennessee-the upper Tennessee River Basin, the lower Tennessee River Basin, the Mississippi Embayment, and the Mobile River Basin.

\section{USGS office locations}

The USGS has 69

employees in Tennessee

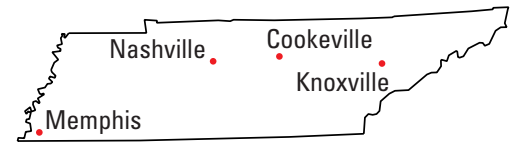

\section{USGS State Representative}

640 Grassmere Park Drive, Suite 100

Nashville, TN 37211

(615) 837-4700

FAX (615) 837-4799

USGS Home Page http://www.usgs.gov Reports and products 1-888-ASK-USGS

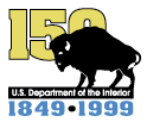

